\title{
THE EFFICIENCY OF ZAKAT COLLECTION AND DISTRIBUTION: EVIDENCE FROM DATA ENVELOPMENT ANALYSIS
}

\author{
Ninda Ardiani * \\ Universitas Airlangga
}

\begin{abstract}
The aim of this study was to see the efficiency of the Dompet Dhuafa national amil zakat institution in fundraising and distribution. Dompet Dhuafa is a national amil zakat organization that has branch offices speard in Indonesia. The problem is how efficient the zakat institution is when collecting zakat funds and distributing them. This study uses the Data Envelopment Analysis (DEA) Method with two tests, namely testing for zakat funds and testing for non-zakat funds. Data was taken from the Dompet Dhuafa financial report from 2011 - 2015. The results of this study addressed 2011,2014 and 2015 Dompet Dhuafa in collecting and distributing zakat funds and their non-zakat funds were efficient. The inefficiencies that occurred in 2012 and 2013 were due to the lack of optimal distribution of funds from the dhuafa wallet. Efficiency in Dompet Dhuafa for the past two years indicates that Dompet Dhuafa as the National Amil Zakat Institution has good credibility and has gained good trust from the people in Indonesia
\end{abstract}

Keywords: Zakat; Efficiency; Performing; DEA,

\begin{abstract}
Abstrak
Tujuan penelitian ini adalah untuk melihat efisiensi dari lembaga amil zakat nasional Dompet Dhuafa dalam pengumpulan dana dan penyalurannya. Dompet Dhuafa merupakan lebaga amil zakat nasional yang memiliki kantor cabang yang tersebar di Indonesia. Permasalahhnya adalah seberapa efisien kah lembaga zakat ketika menghimpun dana zakat dan menyalurkannya. Penelitian ini menggunakan Metode Data Envelopment Analysis( DEA) dengan dua kali pengujian yaitu uji untuk dana zakat dan uji terhadap dana non-zakat. Data d ambil dari laporan keuangan Dompet Dhuafa dari tahun 2011 - 2015. Hasil penelitian ini menujukan tahun 2011,2014 dan 2015 Dompet Dhuafa dalam menghimpun dna menyalurakan dana zakat dan dana non-zakatnya sudah efisien. Ketidakefisiensi yang terjadi di tahun 2012 dan 2013 dikarenakan belum optimalnya penyaluran dana dari dompet dhuafa. Efiisiensi di Dompet Dhuafa selama dua tahun terkahir menandkan bahwa Dompet Dhuafa sebagai Lembaga Amil Zakat nasional memiliki kredibiltas yang baik dan sudah mendapatkan kepercayaan baik dari masyarakt di Indonesia.
\end{abstract}

Kata kunci: Zakat; Efisiensi; Kinerja; DEA. 


\section{INTRODUCTION}

Indonesia is a country with the largest Muslim population in the world, it is described in the Population Census in 2010 showing 87\% of the population in Indonesia are Muslim. Zakat is one of thebow $\mathrm{n}$ Worship Islam and to All a h even equated with Salat. If it does not do so get sanctions and those who run it will get a reply from God, either directly in the world or in the hereafter. A Muslim is obliged to issue zakat if they are free, have reached their age, have reason, and have a perfect ratio. Zakat must be issued if you have fulfilled the requirements for tithe, among others have reached Nisab, have been owned for a year, the amount has been determined and the requirements have been fulfilled (Ryandono: 2008).

according to Huda (2012) Zakat is one of the umpteenth social teachings in benefit-oriented Islam. Zakat is one way to distribute wealth (assets) in an economy, especially from the lucky or rich to those who are less fortunate (poor) in terms of seeking sustenance (Ryandono, 2008). This indicates that zakat is one of the right instruments in alleviating poverty not only within the scope of the Muslim community but also within the state.

Zakat should be collected by the state or the government which acts as a poorpoor representative to obtain the rights that are in the wealth of rich people (Ali, 2012).As instructed by Allah on QS. At-Taubah: 103 that the Prophet Muhammad was ordered to collect zakat from the rich. And also the orders of the Prophet Muhammad to Friends of Muadz bin Jabal to Yemen to withdraw zakat from the rich people there and distribute it to the needy-poor among them (HR. Bukhari).

According to Ali (2012), the way to transfer or equalize wealth is intended so that the rich do not feel that the zakat that is issued as kindness is not an obligation and the poor do not feel indebted to the rich because they receive the distribution of zakat. If the state does not have its own zakat collection institution, collection and distribution of zakat can be done for example by private legal entities under government supervision (Qardhawi in AA Basyir, 1978).

The development of zakat management in Indonesia is strongly influenced by the government (Nasution, 2009). For example, in the Dutch colonial era, the management of zakat tended to be hindered by the Colonial Government because it 
was alleged to finance the struggle against the Dutch Government. While the beginning of Indonesian independence, the government had not paid too much attention to zakat management and was preoccupied with maintaining Indonesia's independence. So that the management of zakat is managed individually or in certain community groups.

Along with the increasing involvement of zakat management institutions, especially non-governmental institutions, the government is also increasingly aware that zakat institutions and regulations have been made in Indonesia. In early August 1999, Minister of Religion A. Amalik Fadjar, read out the Draft Bill on Management of Zakat in front of the DPR-RI plenary session. After a long struggle, on September 23, 1999 President BJ Habibie ratified Law No. 38/1999 concerning Management of Zakat which consists of 10 Chapters and 25 Articles. In this article, it discusses: 1) the objectives and management of zakat management; 2) the establishment of governmental amil zakat institutions; 3) the recognition of nongovernmental amil zakat institutions; 4) the establishment of a Zakat Collection Unit (UPZ) can be established either within or outside the country as an extension of the BAZ in collecting zakat; 5) zakat can be used as a tax deduction; and 6) the need for supervision of the performance of the amil zakat agency

Zakat is the basic word (masdar) of zakaa which means blessing, growing, clean and good. Something that is zaka means to grow and develop. And that person zaka means that person is good (Qaradawi: 2011). Zakat in terms of jurisprudence means that a certain amount of property required by Allah is left to the rightful person, besides issuing certain levels of their own. The amount released from wealth is called zakat because what is spent adds a lot, makes more meaningful and protects that wealth from destruction. Ibn Tamiyah said that the soul of the tithe becomes clean and wealth will be clean too: clean and increasing in meaning. The word zakat in the Koran is mentioned thirty times, where dupuluh seven times is mentioned in one verse together with prayer and only one time is mentioned in the same context as prayer but not in one verse.

According to Law No. 23 of 2011 concerning Management of Zakat, the definition of zakat is a property that must be issued by a Muslim or business entity 
to be given to those entitled to receive it in accordance with Islamic law. So from various notions of zakat, it can be concluded that the notion of zakat in general is a number of assets that must be issued by a Muslim who has fulfilled his requirements to be handed over to those entitled to receive it.

The word "channeling" in the Large Dictionary of Indonesian Language comes from the word "channel" which means: flow, direction. The verb is to channel which means: flowing; directing;continue; and distribute. Own distribution means the process, method, or act of channeling (Ministry of National Education, 2008). While zakat itself is a certain amount of assets issued by people who are obliged to issue it to be given to people who have the right to receive it (mustahik). So the purpose of distributing zakat is the act of distributing certain assets from the obligatory zakat to the recipient of zakat.

The assets of zakat collected must be distributed to 8 (eight) ashnaf (groups) who are entitled to receive zakat ( mustahiq) which consists of: 1) indigent people who do not have sufficient assets or business to fulfill their daily needs; 2) poor people who are unable to meet their basic needs; 3 ) amil zakat, namely those who are assigned by the Imam or head of government to collect zakat and manage it; 4) mu'allaf ie people who have just converted to Islam and are expected to be gentle with Islam; 5)riqab is a slave who will free himself; 6) gharim, which is a person who is in debt who spends all his wealth and is difficult to pay; 7) sabilillah, the one who fights in the way of Allah; 8) Ibn Sabil is aperson who travels with the purpose of goodness, but he lacks the provision to reach his destination.

The benefits of distributing zakat, as stated by Yusuf Qardhawi in Sholeh (2010) can be divided into 3 namely benefits for muzakki , mustahiq, and society in general. The benefits of zakat for muzakki, namely, zakat purifies the soul from stingy nature, educates people and gives, has a moral character, is a manifestation of gratitude for Allah's favor, treats the love of the world, develops inner wealth, attracts sympathy / love, and can develop wealth. The benefits of zakat for mustahiq (zakat recipients) are among others to help fulfill the needs of life mustahiq and can eliminate hatred and envy towards wealthy people who are mischievous. While the benefits of zakat for the community that zakat is of economic value, realize the 
function of assets as a means of struggle to uphold the religion of Allah (jihad fii sabilillah ), and realize the socio-economic justice of society in general.

As prayer becomes the pillar of religion, zakat is the pillar of society, which if not fulfilled can undermine the socio-economic joints of society, because indirectly the detention (non-fulfillment of zakat) from rich people is structural poverty engineering. Zakat which has a social dimension in addition to the sacred dimension, if it is not fulfilled, it will have a negative impact in the form of social vulnerability such as unemployment and other social problems.

aw Number 23 Year 2011 concerning Management of Zakat Article 1 paragraph 2 stipulates that the management of zakat is carried out by the national amil zakat body and amil zakat institution. The arrangement of the establishment of zakat management institutions is indeed important considering the potential of zakat in Indonesia, where the majority of the population is Muslim, of course large. The zakat management institution stated in the law as the Amil Zakat Agency (BAZ) and the Amil Zakat Institution (LAZ).

National Amil Zakat Agency (hereinafter abbreviated as BAZNAS) is an organization that manages zakat formed by the government. BAZNAS is located in each district / city. The main segment of BAZNAS is officials and employees in government circles such as officials, bureaucrats, Civil Servants (PNS) in the district / city government with the mechanism of income zakat payment (zakatmaal ) can be done by deducting salaries directly with the approval of PNS or direct payments voluntary by the civil servants concerned. Even so, in fact not all civil servants distribute their zakat through BAZNAS and BAZNAS also receive zakat paid by the general public.

Unlike the BAZNAS which is managed by the government, the Amil Zakat Institution (hereinafter abbreviated as LAZ) is an organization that manages zakat formed by the community to support the empowerment of zakat by BAZNAS. LAZ is required to be registered as an Islamic community organization engaged in education, da'wah and social affairs, in the form of legal entities, generally foundations and approved by BAZNAS. The existence of BAZNAS and LAS in Indonesia does not make the two amil zakat compete in getting muzakki. 
Competition that occurs is more of a fastabiqul khoirot (competing in goodness) by inviting people to fulfill the third pillar of Islam, namely paying zakat .

In Law 12 of 1999 article 12, the collection of zakat is carried out by amil zakat by receiving zakat from the muzakki or by collecting it from muzakki on the basis of the notification of muzakki. The obligation to pay zakat is not solely given to the consciousness of the muzakki, but it also becomes the responsibility of the zakat collector or amil. At the time of the Prophet and his companions, the collection of zakat was carried out by amil zakat by collecting or collecting from the muzakki. This is done considering the position of zakat which is quite significant in Islamic teachings. Even Islam calls for war against those who are reluctant to pay zakat, as happened in the early days of the Caliph Abu Bakr's administration.

On the collection side, there are many aspects that must be done, such as aspects of counseling, education, and others. This aspect occupies a key function for the success of collecting zakat funds, infaq and shodaqoh. One of the tools that can be utilized is such as the Friday sermon medium, majelis taklim, newspapers, magazines, brochures that are practical in nature that contain assets that must be zakat and how to calculate them, will greatly help efforts to socialize zakat, infaq and shodaqoh.

Imam Qurtubi in Hafidhuddin (2002) states that Al-Amil is the people who are assigned (by the imam / government) to take, write, count, and record the zakat which is taken from the muzakki to then be given to those entitled to receive it. According to Ad Dimasyqi (2005), the notion of amil zakat according to fiqh terminology is people appointed by the imam (government) to regulate the affairs of zakat, which covers the process of collecting, recording, distributing, and so on.

People who include amil zakat are people who are in charge of guarding the assets of zakat, herdsmen of zakat animals and clerks who work in amil zakat offices (Sabiq, 1978). Allah Subhanahu Wata'ala has ordered the Amil organization to collect zakat from the muzakki and distribute the zakat assets to eight groups who are declared entitled to get zakat. As Allah SWT commands in the Qur'an as follows: "Take zakat from some of their property, with that zakat you cleanse and 
purify them and pray for them. Verily your prayer will be for them. And Allah is ever heard, knowing. "(Surah At-Taubah [9]: 103)

The management of zakat in Indonesia is currently mostly carried out by agencies or institutions formed directly by the government (BAZ) and institutions formed independently by a group of people who have been formalized by the government (LAZ). Decree of the Minister of Religion (KMA) Chapter I article I / I, zakat managers consist of elements of society and government with the task of collecting, distributing and utilizing zakat according to Islamic law.

The development of the Amil Zakat Institution which continues to increase from year to year indicates that zakat has been received by the Indonesian people. People can pay their zakat obligations by channeling them through zakat institutions. The Zakat Institution is also obliged to channel the funds. The problem is how efficient the zakat institution is when collecting zakat funds and distributing them.From the Republika Online article on December 11, 2015 it was known that the Achievement of National Zakat is Still One Percent, in the article it was explained that the Potential of Zakat reached Rp. 217 trillion, but the achievement is only Rp. 3.8 trillion. This was caused by public distrust at the Amil Zakat Institution, so the muzaki preferred to channel their own zakat funds.

Dompet Dhuafa is one of the National Amil Zakat Institutions which has been established since 1993 and was approved by the Ministry of Religion as an Amil Zakat Institution since 2001. The credibility of Dompet Dhuafa is not recurred by the presence of branches spread across Indonesia and already having representative offices overseas. The access provided by Dompet Dhuafa is easy to collect zakat funds into more value than the National Amil zakat institution.

Mulyasa in the IZDR (2011: 57) defines performance as "work performance, work performance, achievement of work, work results and performance". The performance of zakat institutions will be seen in the strategies of the zakat institution in optimizing collection, distribution and utilization. Trust in Law No. 23 of 2011 concerning Management of Zakat outlined that in order to increase the usability and results of use, zakat must be managed institutionally in accordance with Islamic law. 
IZDR (2011: 96) measures the economic performance of zakat institutions or Zakat Management Organizations (OPZ) in several indicators, namely: first, the criteria and mechanism for identifying mustahik. Mustahik is the party entitled to receive zakat, which has been explained in QS. Al-Quran [9]: 60 that zakat is only distributed to 8 (eight) groups, namely: 1) indigent people, 2) poor people, 3) zakat administrators, 4) converts who are persuaded by their hearts, 5) to liberate the slaves ( riqab ), 6) those who are in debt ( gharimin ), 7) for the way of Allah ( fisabilillah ), and 8) for those who are on their way ( ibn sabil ).

Second, the growth in the number of mustahik empowered by zakat. The increase in the number of mustahik and the distribution of regions which are the distribution areas of zakat institutions, either through direct distribution of zakat funds or through zakat fund utilization programs will be a parameter of the effectiveness of the zakat institution's performance in carrying out its functions. The success parameter of the zakat institution is that many mustahik are empowered or "moved positions" from mustahik to be munfiq (people who are able to inflate) and can eventually become muzakki.

Third, the growth in the number of muzakki. This third indicator can be measured by the growth in the number of muzakki who entrust their funds to zakat institutions. Fourth, innovation in the utilization of zakat programs. The zakat fund utilization program undergoes a phase of development from program ideas to the implementation of the contribution that is transformed into community empowerment. Fifth, distribution of zakat distribution area. The performance of zakat institutions can be measured from the area of distribution of zakat funds that are reached by zakat institutions.

Sixth, responsiveness to humanitarian emergency response. Zakat institutions play a strategic role as a community institution that is responsive to humanitarian emergency response. Seventh, the utilization of zakat for productive economic activities. Zakat funds are expected not only for the purposes of activities that are charitable. Zakat institutions are required to manage every Rupiah zakat fund more effectively. Most of the mustahik are classified as productive age, so that they can be helped by the utilization of zakat funds productively. And eighth, is the 
intensity of utilization of zakat for the activities of community development and empowerment .

Efficiency analysis is one of the calculation techniques that can measure the unit performance of an organization. Efficiency analysis is needed to find out the use of organizational inputs or resources inproducing output. If in an amil zakat institution it is known that it is not efficient in the use of the inpur, then the zakat institution can evaluate the use of these inputs so that inefficiency does not occur. The method according to the analysis efficiency d Hada et al (2003: 2) is able to know which organizational unit that has the efficiency of the use of fatherly input mengashilkan ang outuput maximum. This method of efficiency analysis that is widely used today is the method of Data envelopment anaysis (DEA) because the DEA approach does not require much information so that less data is needed and fewer assumptions are needed.

In the Ahmad and Masturah Ma'in Journal entitled the efficiency of zakat collection and zakat distribution using a 2 stage analysis explaining the research on the efficiency of Selangor zakat institutions in Malaysia. In this study, it was found that the collection and distribution of zakat possessed resources that were left behind which caused technical efficiency. Then the results of data processing were found that the distribution had a lower efficiency than the collection .

\section{RESEARCH METHODS}

This study uses a qualitative method by testing the data using (Data Envelopment Analysis) Model. DEA testing will be done twice. The first test is to test the efficiency of the collection and distribution of Zakat funds, and the second test is to test the effectiveness of the collection and distribution of non-zakat funds. The input from the first Test is the collection of Zakat funds taken from the Cash Flow report, while the output is the distribution of funds for group 8 of Asnaf. The second test of the input consists of collecting infaq, infaq, and waqf funds, while the output is the distribution of funds for education, health, social, economic, humanitarian, advocacy and network development.Conducting the Test twice is because the zakat 
fund allocation is clear for asnaf 8 groups and should not be channeled other than them

The secondary data of this study were obtained from the financial statements of the Dompet Dhuafa Financial Report that can be accessed at https://www.dompetdhuafa.org/media_file/media/laporan-keuangan

Furthermore, library collection is conducted by reviewing literature books, journals, papers and the internet to obtain a theoretical and developmental basis for the Dompet Dhuafa Amil Zakat Institution. Data was taken from financial statements for 2011 - 2015. Sampling was carried out by taking data on zakat, infaq, and waqf funds receipts as well as data on fund disbursement for Asnaf's 8th group.

Tabel 1. Input Variables and Output Variables for Zakat Fund Efficiency Test

\begin{tabular}{|c|c|c|}
\hline No & Variabel & Source \\
\hline & Input Variables & \\
\hline \multirow[t]{2}{*}{1.} & Zakat Fund & Activity Report \\
\hline & Output Variables & \\
\hline 1. & Distribution for Fakir Miskin & Fund Changes Report \\
\hline 2. & Channeling to Gharimin & Fund Changes Report \\
\hline 3. & Distribution for Ibn Sabil & Fund Changes Report \\
\hline 4. & Channels for Converts & Fund Changes Report \\
\hline 5. & Distribution For Fisabilillah & Fund Changes Report \\
\hline 6. & Distribution For Amil & Fund Changes Report \\
\hline
\end{tabular}

Tabel 2. Input Variables and Output Variables for Non-Zakat Fund Efficiency Test

\begin{tabular}{lll}
\hline No & Variabel & Source \\
\hline & Input Variables & \\
1. & Infaq Fund & Activity Report \\
2. & Infaq Funds Bound & Activity Report \\
3. & Waqf Fund & \\
& Output Variables & \\
1. & Distribution of Education Program & Activity Report \\
2. & Health Program Distribution & Activity Report \\
3. & Social Community Program Distribution & Activity Report \\
4. & Distribution of Economic Programs & Activity Report \\
5. & Disbursement of Humanity Program & Activity Report \\
\hline
\end{tabular}




\begin{tabular}{lll}
\hline 6. & Distribution of Advocacy Programs & Activity Report \\
7. & Distribution of Network Development & Activity Report \\
& Program & \\
\hline
\end{tabular}

Sampling in this study was conducted by purposive sampling, meaning that the sample selection method was chosen based on judgment ( judgment sampling ) which means the selection of samples that are not random whose information is obtained with certain considerations. Analysis of the efficiency of the performance of the Dompet Dhuafa Amil Zakat Institution uses DEA to measure efficiency performance.

The Da Envelopment Analysis (DEA) is one of the non analysis techniques parametric is commonly used to measure efficiency relatively well between profitoriented business organizations (profit oriented ) and between organizations or nonprofit oriented economic activity actors who in the production process or activities involve the use of certain inputs to produce certain outputs. Aside from being a tool for measuring base efficiency, DEA can also be used as a policy-making tool to increase efficiency. In particular, DEA is the development of linear programming techniques in which there are objective functions and constraint functions. The following are general equations in the Data Envelopment Analysis (DEA) method (Paradise and Hosen, 2013: 172-175). DEA is a non-parametric approach based on linear programs ( Linear Programming ) with the help of efficiency software packages, and this research will use OSDEA software .

\section{RESULTS AND DISCUSSION}

The role of zakat in the economy is related to the nature of worship of zakat which is related to the wealth of Muslims. Zakat in the economy can be likened to a mechanism for the redistribution of assets from the muzakki group to mustahik. As is known, mustahik is a group that has the right to receive zakat which includes eight groups, namely the destitute, the poor, amil zakat, Muslim converts, riqab (slave servants), gharim (people in debt), fi sabilillah (activities in the way of Allah), and ibn sabil (traveler who runs out of stock). The mustahik sequence above shows the priority of distributing zakat in terms of the socio-economic perspective, 
with the poor and the poor becoming groups that need to be given the highest priority in the distribution and utilization of zakat. The benefits of distributing zakat, as stated by Yusuf Qardhawi in Sholeh (2010) can be divided into 3 namely benefits for muzakki ,mustahiq, and society in general. The benefits of zakat for muzakki, namely, zakat purifies the soul from stingy nature, educates people and gives, has a moral character, is a manifestation of gratitude for Allah's favor, treats the love of the world, develops inner wealth, attracts sympathy / love, and can develop wealth

Al Qardhawi said that the aim of the zakat service was to solve various kinds of social problems such as unemployment, poverty and so on. The zakat distribution system itself is a solution to this problem by providing assistance to the poor regardless of race, color, ethnicity and other worldly attributes (Qardhawi, 2005: 36) The role of zakat in moving the economy and transforming morality requires synergy among stakeholders zakat One of them is collaboration between the Amil Zakat Institution (LAZ) and the campus. LAZ as a zakat practitioner requires the campus to provide academic studies as an evaluation material and provide new ideas for LAZ to develop programs run by LAZ. On the other hand, the campus needs LAZ to provide empirical management of zakat experience to be used as material for research, research and community service on campus. This is inseparable from the role ofthe campus to run the Tri Dharma Perguran Tinggi, namely education, research and community service.Collaboration that needs to be initiated is also a synergy between LAZ and Baitul Mal wa Tamwil (BMT). On the one hand, LAZ as a social institution is basically related to the social function of BMT in the form of the Baitul Mal. LAZ and Baitul Mal can work together to optimize the collection of zakat from BMT members and produce social funds from LAZ through the Baitul Tamwil from BMT

The existing data will be processed use Data Envelopment Analysi s with twice Test ,.The first test was carried out to see the efficiency of the Zakat Fund of the Amil Zakat Dhuafa Institution, then the second test to see the efficiency of the Non-Zakat Funds of the Dompet Dhuafa Amil Zakat Institution. Data in the test to find out the overall efficiency of Dompet Dhuafa. Using DEA, the data that is 
processed and the results that show number 1 show efficiency. Whereas the number below 1 shows that it is not yet efficient, the closer to number 1 shows better efficiency.

\begin{tabular}{lll}
\multicolumn{3}{l}{ Tabel 3. Results of DATA Processing using ZAKAT funds. } \\
\hline DMU Name & \multicolumn{1}{c}{ Objective Value } & Efficient \\
\hline 2011 & 1 & Yes \\
2012 & 0,824804907 & \\
2013 & 0,801779633 & \\
2014 & 1 & Yes \\
2015 & 1 & \\
\hline
\end{tabular}

Source: Processing Results 2017

From the table, it is known that in 2011, 2014 and 2015 there was efisein in processing zakat data at Dompet Dhuafa. This is indicated by the objective value 1 . Every year zakat fund receipts always increase as well as the distribution for asnaf 8 groups. But this increase in 2012 and 2013 left zakat funds. This indicates that in that year the distribution of zakat funds was less efficient. This is indicated by the objective value of 0.824804907 in 2012 and 0.801779633 in 2013. In 2011, 2014 and 2015 it was optimal because there were no remaining funds but the existing zakat funds experienced a difference.

\begin{tabular}{|c|c|c|}
\hline DMU Name & Objective Value & Efficient \\
\hline 2011 & 1 & \\
\hline 2012 & 0,577886072 & \\
\hline 2013 & 0,742518551 & \\
\hline 2014 & 1 & \\
\hline 2015 & 1 & Yes \\
\hline
\end{tabular}

From the table for processing non-zakat data, namely data on infaq fund collection, bound infar and endowments and their distribution for education, health, social, economic, humanitarian, advocacy and network development activities, it is found that in 2012 it was inefficient because of processing results DEA data the value of the objective value shows the value of 0.577886072 . This value indicates tid a k efficiency of collection and distribution of non-zakat funds in Wallet poor. In 2011, 2014 and 2015, from the results of DEA data processing, there was efficiency in the performance of Dompet Dhuafa in collecting and matching the 
Non-Zakat funds. The low value can be due to too large an output value that is not balanced with the input value.

From the results of data Olah DEA to performance d o mpet orphans to be tested twice to see the efficiency of the performance of the collection and distribution of zakat funds and the performance of the collection and distribution of zakat funds in the form of non- INFA, infaq bound and endowments during 20112015 dii know at 2011, 2014 and 2015 have been efficient because the value of the objective value has shown number 1 .

In 2011 both data processing and zakat and non-zakat funds were effective. In managing zakat funds it can be seen that in that year the value of efficiency is obtained from the difference in zakat income and its distribution. In 2011, the distribution of zakat funds was greater than the collection.

In contrast to 2011, in 2012 and 2013 the objective value of the results of DEA processing showed a number less than 1, which indicates that in that year the collection and distribution activities were not yet efficient. Knowledgeable from the cash flow reports that existed in 2012 and 2013 there was a difference in the receipt and distribution of the larger zakat funds at his receipt. The remaining or excess of the zakat funds indicates that the management or performance of the dimpet of the poor in the year is inefficient.

As in 2011, in 2014 and 2015 the efficiency of Dompet Dhuafa's performance showed efficiency with its objective value 1 . This indicated that in that year the process of managing zakat funds both in collection and distribution was efficient. Financial reports in 2014 and 2015 showed a difference in the income of zakat funds and their distribution. Receiving Zakat funds is less than the distribution, as happened in 2011.

Processing of non-Zakat data with DEA from 2011 - 2015 is not different from the processing or zakat funds. In 2011-2014 and 2015 the management of Non-Zakat funds (Infaq, Infaq bound and Endowments) has been effective with the objective value already number 1. Whereas in 2012 and 2013 it was still not effective because the objective value was still below number 1, namely 0.577886072 and 0.742518551 . 
Efficiencies in Dompet Dhuafa for the past two years indicate that Dompet Dhuafa as the National Amil Zakat Institution already has more credibility and has gained more trust from the people in Indonesia. Not yet optimal, zakat institutions in 2012 and 2013 can be neutralized with efficiency in the following year.

\section{CONCLUSION}

People can pay their zakat obligations by channeling them through zakat institutions. The Zakat Institution is also obliged to channel the funds. The problem is how efficient the zakat institution is when collecting zakat funds and distributing them. Dompet Dhuafa is one of the national amil zakat institutions that has good credibility.

From the data collected from 2011 - 2015, both zakat and non-zakat funds show the efficiency of the performance of the amil zakat institution in 2011, 2014 and 2015. Whereas in 2012 and 2013 there was no efficiency due to several things, one of which was distribution of funds that have not been optimal. Efficiency of Dompet Dhuafa During 2011, 2014 and 2015 shows that the dhuafa wallet has become one of the national amil zakat institutions that has good credibility value. Dompet Dhuafa can also be accepted in the community and can serve the community to distribute their zakat.

\section{REFERENCES}

Ali, Mohammad.2009. Pendidikan untuk Pembangunan Nasional: Menuju Bangsa Indonesia yang Mandiri dan Berdaya Saing Tinggi. Jakarta: Intima.

Ali, Mohammad Daud. 2012. Sistem Ekonomi Islam Zakat dan Wakaf. Jakarta: UI Press.

Ash-Shiddieqy, M Hasbi.2009. Pedoman Zakat. Pustaka Riski Putra: Semarang

Badan Amil Zakat Nasional (BAZNAS). 2013. Mengoptimalkan Potensi Zakat dengan Sistem. Majalah Zakat: Edisi Mei-Juni 2013 M/Rajab 1434 H.

Chapra. 2000. Islam dan Pembangunan Ekonomi, terj. Ikhwan Abidin Basri. Jakarta: Gema Insani Press.

Departemen Agama RI. 2009. Al Qur'an dan Terjemahannya. Bandung: Jabal Raudhotul Jannah. 
Depdiknas. 2008. Kamus besar Bahasa Indonesia Pusat Bahasa. Jakarta: PT Gramedia Pustaka.

Hadad, M, dkk. 2003. Analisis Efisienfi Industri Perbankan Indonesia: Penggunaan Metode Non Parametrik Data Envelopment Analysis, working paper Bank Indonesia.

Hafidhuddin, Didin. 2002. Zakat dalam Perekonomian Modern. Jakarta: Gema Insani Press.

2007. Agar Harta Berkah dan Bertambah: Gerakan Membudayakan Zakat, Infak, Sedekah, dan Wakaf. Jakarta: Gema Insani Press.

Huda, Nurul, dkk. 2012. Keuangan Publik Islam: Pendekatan Teoritis dan Sejarah. Jakarta: Kencana.

IZDR (Indonesia Zakah \& Development Report).2011. Kajian Empirik Zakah Dalam Penanggulangan Kemiskinan. IMZ

Nasution, Mustafa Edwin. 2006. Pengenalan Eksklusif Ekonomi Islam. Cetakan I. Jakarta: Kencana Prenada Media Group.

Nurul Huda, dkk. 2015. Zakat Prespektif Mikro-Makro : Pendekatan riset. Prenamedina Group: Jakarta

dkk. 2014. Solution to Indonesian Zakah Probelmatic Analytic Hierarchy Proses Aproach. Journal of Islamic Economics, Banking and Finance, Vol 10 No 3 July - Sep 2014

Qardawi, Yusuf. 2011. Hukum Zakat: studi komperatifmengenai status dam filsafat zakat berdasarkan Al quran dan Hadis cetakan keduabelas. Pustaka Litera Antar Nusa: Bogor.

2005. Spektrum Zakat dalam membangun Ekonomi Kerakyatan. Jakarta: Zikrul Hakim.

Ryandono, Muhammad Nafik Hadi. 2008. Ekonomi ZISWAQ (Zakat, Infaq, Shadaqah, Waqaf). IFDI dan Cenforis: Surabaya

Saad, Norma dan Nazarudin Abdulah. 2014 : Is Zazat Capable Alleviating Poverty? An Analysis the Distribution of Zakat Fund in Malaysia. Journal of Islamic Economic,Banking, ... vol-10 No. 1 January - march April

Surat Keputusan Menteri Agama RI Nomor 373 Tahun 2003 Tentang Pelaksanaan Undang-Undang Nomor 38 Tahun 1999 Tentang Pengelolaan Zakat. 